\title{
レーザーを用いた磁気リコネクションの研究
}

\author{
森高外征雄 \\ 核融合科学研究所ヘリカル研究部 基礎物理シミュレーション研究系 (†509-5292 岐阜県土岐市下石町322-6)
}

\section{Experimental Studies on Magnetic Reconnection Using Lasers}

\author{
Toseo MORITAKA
}

The Fundamental Physics Simulation Research Division, Department of Helical Plasma Research, National Institute for Fusion Science, 322-6 Oroshi-Cho, Toki, Gifu 509-5292

(Received May 23, 2016)

\begin{abstract}
Magnetic reconnection plays a key role in the rapid release of magnetic energy and the transition of magnetic field topology in space and astrophysical plasmas. Various experimental studies have been proposed and demonstrated magnetic reconnection with intense lasers. The configurations of a strong magnetic field, as well as laser-produced plasma, are essential in experimental designs. This paper introduces recent experimental studies by classifying the sources of strong magnetic fields.
\end{abstract}

Key Words: Magnetic reconnection, Laser-produced plasma, Strong magnetic field, Space plasma

\section{1.はじめに}

磁気リコネクションとは，プラズマ中で磁力線がつな ぎ変わる現象のことを指す ${ }^{1)}$. 電導性の高い磁化プラズ マでは磁力線の凍結原理が成り立ち, プラズマは磁力線 を横切って流れることが出来ない. このとき, 磁化プラ ズマの全体構造は磁力線のトポロジーによって特徴づけ られる，磁気リコネクションは，凍結原理が破れプラズ マの構造遷移が起こる時に普遍的に現れる過程であり, 惑星磁気圈や核融合炉などあらゆるプラズマ環境で重要 となる。

磁気リコネクションの特徵は, 磁化プラズマの全体構 造を決める過程でありながら, それ自体は局所的に起こ るという点である。これは, 急峻な反転磁場中で初めて 凍結条件を破る効果が明確になるためである。その結 果, 磁化プラズマの構造は一様に緩和するのではなく, 磁場エネルギーの急激な解放を伴う突発的な構造遷移を 繰り返していくようになる。このような突発的現象は磁 気圈サブストーム ${ }^{2)}$ ，太陽フレア ${ }^{3)}$ ，トカマクプラズマ の鋸歯状振動 4 など広く観測されており，磁気リコネク ションが共通するメカニズムであると考えられている。

磁気リコネクション現象の全容を解明するためには, 巨視的な構造遷移とリコネクション領域近傍の局所過程 との両面からの理解が不可欠である. 太陽観測や電磁流 体 $(\mathrm{MHD})$ シミュレーションは前者, 地球磁気圈のその 場観測やParticle-in-Cell (PIC) シミュレーションは後者と いったように, 研究手法ごとにカバーできる範囲が限定 されているため, それらの研究成果を相互に補間してい
く必要がある。しかし, 両者の空間スケールの差は非常 に大きく，これらを結びつけていくのは容易ではない. 例えば地球磁気圈の場合, 磁気圈全体のサイズ $10^{6} \mathrm{~km}$ に 対し，PICシミュレーションや衛星観測で捉えられる空 間スケールはイオン慣性長 $(10-100 \mathrm{~km})$ と同程度からそ の100倍までの範囲に収まることが多い ${ }^{5,6)}$.

室内実験による磁気リコネクション研究では磁場の全 体構造をあらかじめ制御した上でリコネクション領域を 狙った計測を行うことができるため, 観測/シミュレー ション研究で得られないリコネクション現象の全体像を 捉えることができる．現在の実験では，トーラス磁場同 士を接触・合体させることで磁気りコネクションを誘発 させるものが主流である。電極放電によってチャンバー 内にプラズマ(温度10-100 eV程度)を発生させ, 大型電 磁コイルによってトーラスやその他の形状の磁場(強度 $1 \mathrm{~T}$, サイズ $1 \mathrm{~m}$ 程度)を作る。これまでの実験では, 凍 結条件を破るメカニズムの探索や外部環境の制御による リコネクション発生条件の解明，プラズマ加熱の実証と いった成果を上げている

高出力/高強度レーザーは新たなプラズマ発生源とし て無衝突衝撃波を始めとした宇宙プラズマ現象の再現に 用いられているが, 近年, 磁気リコネクション研究にも 応用されてきた。実験デザイン上のポイントは, 高エネ ルギー密度プラズマ中で磁気リコネクションを起こすた めの強い反転磁場をどのように生成・制御するかという 点にあり，電磁コイルを用いるほか，レーザーを磁場生 成にも利用する方法が検討されている。このような磁気 リコネクション実験はまだ発展途上であるが, 従来の実 
験では実現できない幅広いプラズマや磁場のパラメータ 領域をカバーできるポテンシャルを持っている。

本稿では, 磁気リコネクションの基本的描像とレー ザーを用いた実験的アプローチについて概説する。第二 章では，磁気リコネクションの基礎的な理論モデルと， 実験を考える上で重要となるパラメータについて説明す る、第三章では，最近実施または提案されているレー ザーを使った磁気リコネクション実験について，磁場の 生成手法で分類しながら代表的なものを紹介する.

\section{2. 磁気リコネクション研究の概要}

磁気リコネクションの基礎的なモデルと, 磁気リコネ クション研究の主な論点について説明する. 最後に, 実 験デザインを特徽付ける主なパラメータについて述べ る. 磁気リコネクションの全容についてはD. Biskampに よる教科書 ${ }^{1)}$ が詳しい. 最近の研究については文献,10)で レビューされている.

\section{1 磁気リコネクションの基本過程}

磁気リコネクションは, Fig. 1(A)のような磁力線面 内構造のもと，定常MHDモデルをベースに議論されて きた。この平面内では反平行な磁力線が接する点 $(\mathrm{X}$ 点) を除いて，凍結原理が成り立っているとする。図の上下 から反平行な磁力線がプラズマとともにX点に流入し $\left(\right.$ インフロー速度 $V_{\mathrm{in}}$ ), ここで凍結原理が破れることで 磁気リコネクションが起こる。つなぎ変わった磁力線は 左右方向に排出される (アウトフロー速度 $V_{\text {out }}$ ). 系が定 常であるため，X点を出入りする磁気フラックスの収支 は釣り合う。リコネクションの速さはこのフラックスの 流入速度で特徴付けられる。磁気リコネクションによる

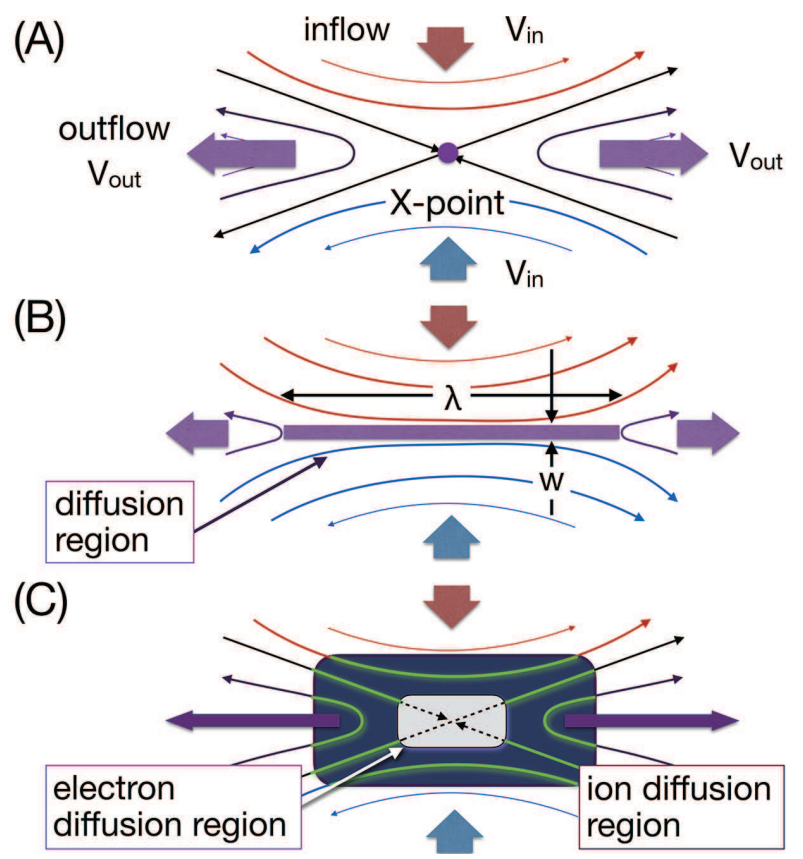

Fig. 1 (A) Basic concept of magnetic reconnection. (B) Sweet-Parker reconnection model. (C) Schematic picture of kinetic collisionless reconnection.
磁場のエネルギー解放は, アウトフロー速度の増加やア ウトフロー側でのプラズマ加熱に対応する.

Sweet-Parker(SP) モデル ${ }^{11,12)}$ (Fig. 1(B)) は, 凍結条件 を破るメカニズムを含む自己無撞着なモデルとして，最 初に提案されたものである。ここでは一様な古典抵抗 (抵抗率 $\eta$ )によって凍結条件が破れるとする。磁場 $\boldsymbol{B}$ の 時間発展は, 誘導方程式 $\partial \boldsymbol{B} / \partial t=\nabla \times(\boldsymbol{V} \times \boldsymbol{B})+\eta \nabla^{2} \boldsymbol{B}$ で表 される。右辺第一項はプラズマの流れVに凍結した磁場 の移流を表し, 第二項 (拡散項)が凍結条件を破る。磁化 プラズマの流入によって反平行な磁力線が狭い領域に密 集し, その結果生じる急峻な磁場勾配のもと, 拡散項が 顕在化する拡散領域が形成される。このモデルでは，ア ウトフロー速度はAlfvén速度 $V_{\mathrm{A}}$ に一致し，リコネクショ ンの速さ (リコネクション率 $\left.\equiv V_{\mathrm{in}} / V_{\mathrm{A}}\right)$ は抵抗率の $1 / 2$ 乗に 比例する，定常状態ではリコネクション率は拡散領域の アスペクト比に等しい $\left(V_{\mathrm{in}} / V_{\mathrm{A}}=w / \lambda\right)$ 。ここで $w$ は拡散領 域の厚さ，入は長さを表す。

宇宙プラズマの多くは高温希薄なため, 古典抵抗が非 常に小さい無衝突プラズマである。例えば，太陽表層で の典型的なプラズマ密度 $10^{9} \mathrm{~cm}^{-3}$ と温度 $100 \mathrm{eV}$ に対して 抵抗率 $\eta$ は $10^{-6} \Omega \mathrm{m}$ とな, 磁気リコネクションの典型 時間 $\left(=L / V_{\text {in }}\right)$ はSPモデルから見積もると 1 年程度になる ( $($ は磁場構造の空間スケール). 宇宙プラズマで起こる フレアやサブストームといった突発的現象は, はるかに

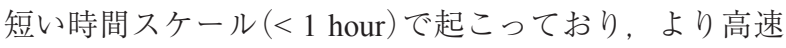
な無衝突磁気リコネクションの存在を示唆している.

無衝突プラズマ中で凍結条件が破れる要因として, 運 動論効果による実効的な散逸効果がある。これは反転磁 場や静電/電磁摇動の下での，電子やイオンのLarmor運 動のひずみに基づいており，Larmor半径や慣性長よりも 小さい空間スケールで現れる。例えばイオンLarmor半径 は太陽表層部分では1-10 m, 磁気圈では100-1000 km と いずれも磁場構造全体からみると非常に小さい。無衝突 磁気リコネクションはFig. 1(C)のように, イオン運動論 効果が現れるイオン拡散領域と, その内部で電子運動論 効果も顕在化する電子拡散領域という, 二つの局所的な 構造を内包していると考えられる.

イオン拡散領域については，二流体効果を考慮した磁 気リコネクションモデル (アウトフローが電子Alfv'en速 度で決まり, 弱い散逸効果の下でもリコネクション率が 高くなる)が整備され, 近年の磁気圈観測やトーラス合 体実験でも詳しく解析されている ${ }^{13-15)}$. 一方, 磁力線の トポロジーは電子の凍結条件によっても保持されるの で，つなぎ変えそのものは電子散逸領域内で起こる ${ }^{16,17)}$. 電子ダイナミクスで決まる非常に小さい空間スケールを 持つため観測・実験から得られる知見は限定的である.

最後に, 磁気リコネクション研究の主要な論点につい て列挙すると (H. Ji：IPELS2015の講演より), (1) 無衝 突プラズマ中でリコネクション率を決定する，または速 いリコネクション（観測では $V_{\mathrm{in}} / V_{\mathrm{A}} \sim 0.01-0.1 ）$ を実現する メカニズム，（2）リコネクションをトリガーする(凍結条 件を破る) メカニズム，（3）エネルギー変換プロセス（プ ラズマ加熱/加速, 非熱的粒子加速), (4) 磁気リコネク 
ションの三次元構造, (5) 大域的な磁力線構造やプラズ マの流れがもたらす影響，（6）巨視的なMHD現象と局所 的な拡散機構とのスケール間相互作用などがある。天体 現象への応用や実験研究の進展により(7)相対論的/輻射 プラズマや, (8) 部分電離プラズマにおける磁気リコネ クションといった論点も重要になってきている。

\section{2 磁気リコネクションの特徴パラメータ}

磁気リコネクションに関連する代表的な特徵パラメー タとして, (a)イオンLarmor半径 $\rho$, (b) Alfvén速度 $V_{\mathrm{A}}$, (c) Lundquist数 ${ }^{18)} S\left(=L V_{\mathrm{A}} / \eta\right.$, Alfvén波の伝播時間と衝突 拡散時間の比)が挙げられる。レーザー実験におけるこ れらのパラメー夕を議論する，以下の見積もりの例では $\mathrm{C}^{3+}$ プラズマを仮定している。

(a) は磁化プラズマの凍結条件を規定している。系全 体のサイズをLarmor半径より大きくとることで凍結条件 を満たす磁化プラズマを作り，その中で磁気りコネク ションを誘発させる，高出力レーザーによって生成され るプラズマは温度10-1000 eV(もしくは噴射速度100$1000 \mathrm{~km} / \mathrm{s}$ ) 程度であることが多い.このとき, Larmor半 径を測定範囲(例えば光学測定の視野サイズ〜 $1 \mathrm{~cm}$ ) より 十分小さくするには1-10 T程度以上の磁場が必要にな る.

(b) はアウトフロー速度やリコネクション率を特徵付 ける。 $V_{\text {in }} \ll V_{\mathrm{A}}$ であれば拡散領域の物理に支配された定 常リコネクションとなるが, $V_{\mathrm{in}} \gg V_{\mathrm{A}}$ の場合, 磁気りコ ネクションよりも衝撃波形成が卓越してくると予想され る。高密度なレーザー生成プラズマ中で, Alfvén速度を 相対的に大きくするためには強い磁場が必要である。密 度 $10^{18} \mathrm{~cm}^{-3}$ を仮定すると, Alfvén速度を100-1000 km/sに するのに要する磁場は10-100 Tになる. Alfvén速度をプ ラズマ流速や熱速度より小さくすることは， $\beta$ 值を 1 よ り小さくすることと等価である.

(c) は, 磁気リコネクションにおいてSPモデルのリコ ネクション率 $\left(=w / \lambda=S^{-1 / 2}\right)$ を特徽付ける. $w$ の下限をイ オン慣性長 $d_{\mathrm{i}}, \lambda$ 限を装置サイズ $L$ とする ルの適用範囲は, $S \ll\left(L / d_{\mathrm{i}}\right)^{2}$ と概算される。磁場 $10-100 \mathrm{~T}$ と温度 $100 \mathrm{eV}$ 仮定すると $\mathrm{S} \sim 100-1000$ となり，イオン 慣性長は密度 $10^{18} \mathrm{~cm}^{-3}$ に対して0.1-1 cm $(\leqq L)$ なので, 単 純なSPモデルではなく無衝突効果が効いてくると考え られる。ただし宇宙プラズマ現象では， $\mathrm{S} \sim 10^{6-10}$ (ある いはそれ以上)とさらに大きくなる.

このように，無衝突磁気リコネクションの再現のため には，レーザーによって生成する高エネルギー密度プラ ズマ中で磁気リコネクションを起こすための, 強い磁場 の確保とその制御が重要になる。

\section{3.レーザーを用いた磁気リコネクション実験例}

磁場の生成方法に着目して, これまでに実施/提案さ れた磁気リコネクション実験から代表的なものを紹介す る。ここでは(1)電磁コイルによる外部磁場19), (2) Biermann battery効果 ${ }^{20)}$ ，（3）コイル付きターゲット ${ }^{24)}$, (4) 短
パルスの超高強度レーザー ${ }^{26)}$ ，を利用した四例を取り上 げる。（1)-(3) では $\rho / L \sim \mathrm{O}(0.01-0.1), \quad S \sim \mathrm{O}(100-1000)$ で, 概ね無衝突磁化プラズマ現象の再現となっている. $V_{\mathrm{A}}$ については，プラズマの低密度部分 (1)やレーザーで 生成される強磁場 (2)の利用により $V_{\mathrm{in}} \leqq V_{\mathrm{A}}$ としている. この場合，プラズマ流で駆動される過渡的なリコネク ション現象を捉えていると考えられる。（3）では両者の 併用によりさらにV $V_{\mathrm{A}}$ が大きくなる。(1) は拡散領域近傍 の構造に注目しているのに対し，(2)では局所的に生成 されるプラズマ全体の計測から太陽フレアのような巨視 的な現象と関係付けている。(4)は現象の空間スケール が, イオン慣性長より小さく，イオン拡散領域内で起こ る電子スケールの磁気リコネクションに言及している. 磁場 $10^{5} \mathrm{~T}$ と強く(電子Alfvén速度～光速度), 相対論効果 についても議論している.

\section{1 外部磁場を用いた実験例}

最初の方法では, ターゲット周辺に配置した電磁コイ ルによって反転磁場を作る (Fig. 2(A) ) ${ }^{19)}$. 対向した薄膜 ターゲットへの高出力レーザーの照射でできる高密度ア ブレーションプラズマ(推定密度〜 $\left.10^{21} \mathrm{~cm}^{-3}\right)$ が, 各コイ ルの磁力線を押し広げることで，コイル間に急峻な反平 行磁場を作る。同時に希薄なプラズマ $\left(\sim 10^{18} \mathrm{~cm}^{-3}\right)$ を背 景に分布させておき, この希薄プラズマ内で起こる磁気 リコネクションを観測する。

コイルの初期磁場は8 T程度とそれほど強くないが,

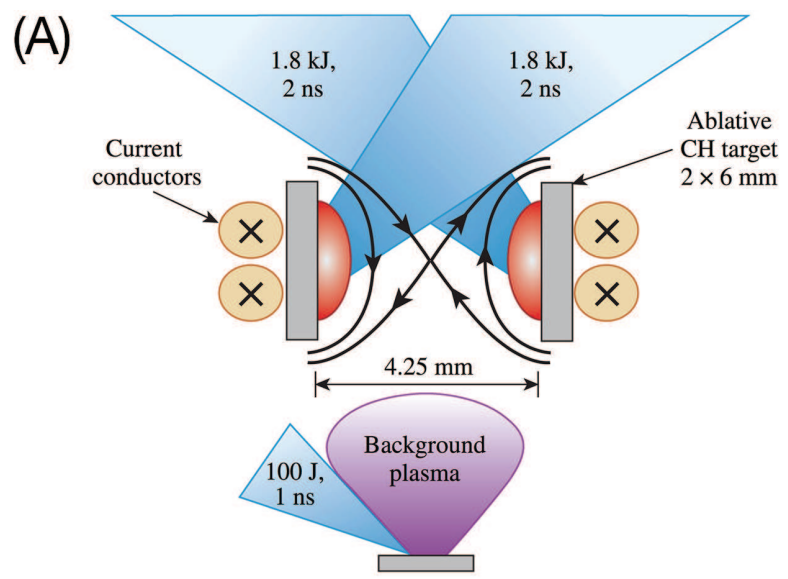

(B)

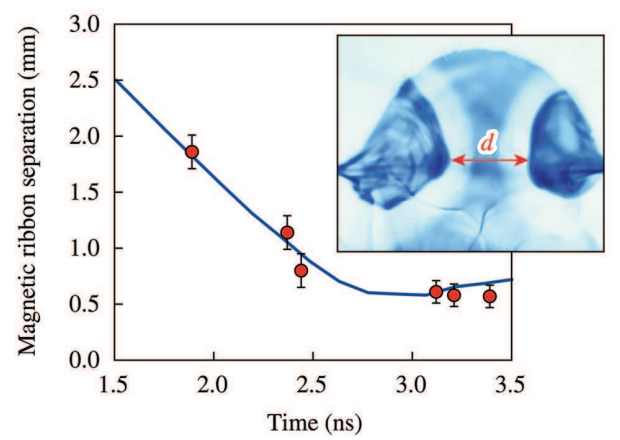

Fig. 2 (A) Experimental setup for reconnection using external magnetic fields. (B) Time evolution of magnetic ribbon separation from experiment (point) and simulation (line). ${ }^{19)}$ 
希薄なプラズマを併用することで $V_{\mathrm{in}} \leqq V_{\mathrm{A}}$ を満たすよう にしている. 反転磁場のサイズが $0.1-1 \mathrm{~cm}$ と大きく初期 磁場構造も明確なため, リコネクション領域を狙った計 測やシミュレーションとの比較は行いやすい. Fig. 2 (B) は, 二つのmagnetic ribbon(拡大するプラズマの端に 集積した磁力線領域)の間隔の時間発展を示している。 プロトンバックライト計測から見積もられた間隔(丸点) はPICシミュレーション(実線)と一致しており，イオン 慣性長程度に落ち着くという結果が得られている。

\section{2 自己生成磁場を用いた実験例}

高出力レーザーを磁場の生成にも使うことで, 局所的 ではあるが非常に強い磁場を作ることができる。一つの 方法は, Biermann Battery効果 ${ }^{20)}$ を用いるものである. この効果は, 電子圧力項を残した誘導方程式 $\mathrm{d} \boldsymbol{B} / \mathrm{dt}=\nabla \times$ $(\boldsymbol{V} \times \boldsymbol{B})+\nabla \times(\mathrm{c} \nabla p / n e)$ の第二項に相当し, 磁場をゼロか ら生成する効果の一つである。 $p$ と $n$ は電子圧力と密度, $c, e$ は光速度と素電荷を表す，レーザー照射点近傍に局 在した高温プラズマが生成されると，この効果によって プラズマをとりまく非常に強いリング状の磁場が生成す る.

レーザーを用いた磁気リコネクション実験の先駆的な 研究 $^{21)}$ では, 固体ターゲット上の二点にレーザーを照射 L (Fig. 3(A)), 一対のリング状磁場を作る. 磁場強度

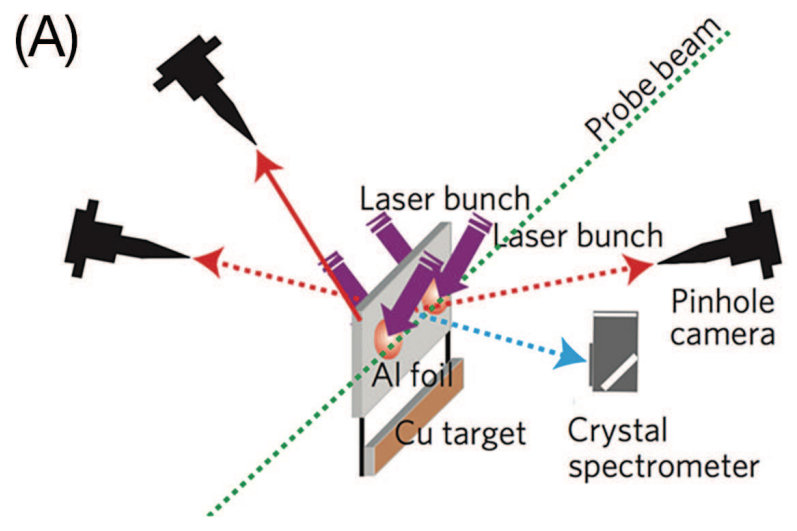

(B)

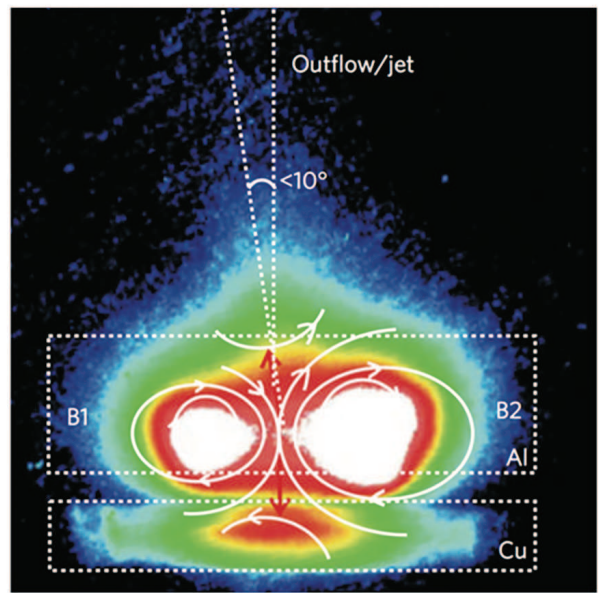

Fig. 3 (A) Experimental setup for reconnection using self-generated magnetic fields. (B) X-ray pinhole image. White lines indicate estimated magnetic field lines. ${ }^{21}$

第 44 巻第 9 号 レーザーを用いた磁気リコネクションの研究
は100 T程度と推定され, 生成したプラズマのサイズ （０.5 mm）に比べてLarmor半径 $(\sim 0.01 \mathrm{~mm})$ は十分小さ い. 二つのアブレーションプラズマは凍結条件を満たし ながら拡大，リコネクションによって合体する。X線ピ ンホールカメラでは，プラズマの接触領域から噴出する ジェット状の構造が捉えられている(Fig. 3(B)). ジェットの速度はAlfvén速度 $(\sim 400 \mathrm{~km} / \mathrm{s})$ 程度であり, リコネクションに由来すると考えられている。この実験 では，ジェットの逆側のプラズマ加熱部分と共に，フレ アで観測される磁力線ループ構造の模擬を目指している.

レーザー生成プラズマの合体による磁気リコネクショ

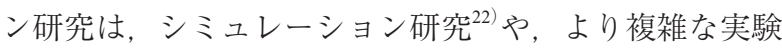
デザイン ${ }^{23)}$ へと進展している.

\section{3 コイル付きターゲットを用いた実験例}

高出力レーザーで強磁場を生成する別の方法として, ヘルムホルツコイルを内蔵したターゲットを用いる方法 がある ${ }^{24)}$.コイルの両端に固体ターゲットがとりつけら れており，その片側にレーザーを照射する．照射側では 高速電子がはじき出され，コイル両端でポテンシャルの 差が生じる結果, コイルに強い電流が流れ，電磁コイル を大きく上回る磁場を生成する。電流の位置が明確なの で，反転磁場の構造を比較的制御しやすくなっている.

実験では，二重のコイルを用いて反転磁場を作ってい る(Fig. 4(A) ) ${ }^{25)}$ ．コイルの間を通したプローブレーザー のファラデー回転角の測定から，60 Tに及ぶ強磁場発生 が確認されている。 また，レーザー照射点から離れたコ イル近傍ではプラズマが比較的希薄になるため, これま での手法よりも $\beta$ 值を低く $(\sim 0.01)$, Alfvén速度を相対 的に大きくすることが出来る。可視自発光計測で観測さ

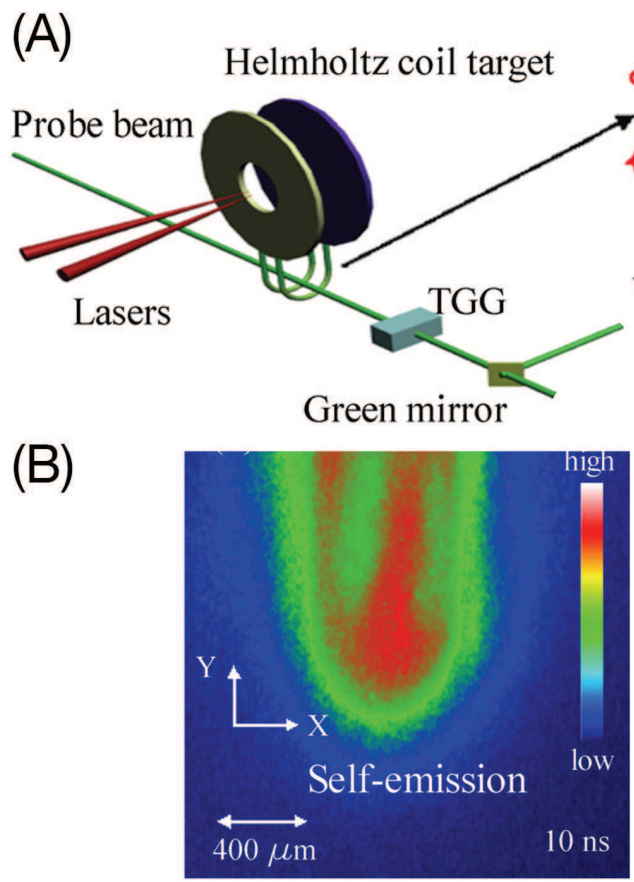

Fig. 4 (A) Experimental setup for reconnection using Helmholtz coil targets. (B) Self-emission image taken at $10 \mathrm{~ns}$ after laser irradiation. ${ }^{25)}$ 
れたコイル間の高密度プラズマ構造は, 磁気リコネク ションのアウトフローが堆積したものと予想されている (Fig. 4(B)).

\section{4 超高強度レーザーを用いた実験提案}

高出力レーザーのかわりに短パルスの超高強度レー ザーを用いれば, 時空間スケールは小さいが, さらに強 い磁場を作り出すことができる。ここでは, 臨界密度に 近いプラズマを集光強度 $5 \times 10^{20} \mathrm{~W} / \mathrm{cm}^{2}$ の円偏光レー ザーが通過したときに生成される磁場を利用する ${ }^{26)}$ 。こ の磁場はプラズマ内部の電子加速によって生じるフィラ メント状の電流によって生成し, レーザー進行方向に対 してらせん状の構造を持つ(Fig. 5(A))。プラズマに二 本の高強度レーザーを平行して照射し, 磁場同士を合体 させて磁気リコネクションを起こす．PICシミュレー ションでは, $10^{5} \mathrm{~T}$ 超える強磁場がプラズマ内部に生 成し, 数十レーザー周期 $(<1 \mathrm{ps})$ の間に磁気リコネクショ ンによって合体していく結果が得られている(Fig. 5(B)).

時間スケールが短いため, 磁気リコネクションを直接 観測するのは難しいが, 電子スペクトルの測定から磁気 リコネクションの形跡を捉えることができる可能性があ る。シミュレーションでは，電子Alfvén速度に対応する 電子加速が見られると予想している。磁場が強く電子 Alfvén速度が大きい(光速の $99.92 \%$ )ため, 電子エネル ギー (Lorentz factor) の増分は $\Delta \gamma \sim 20-50$ に及゙。このよ うに, 超高強度レーザーを用いることで相対論的な磁気 リコネクションにアプローチできるようになるかもしれ ない.
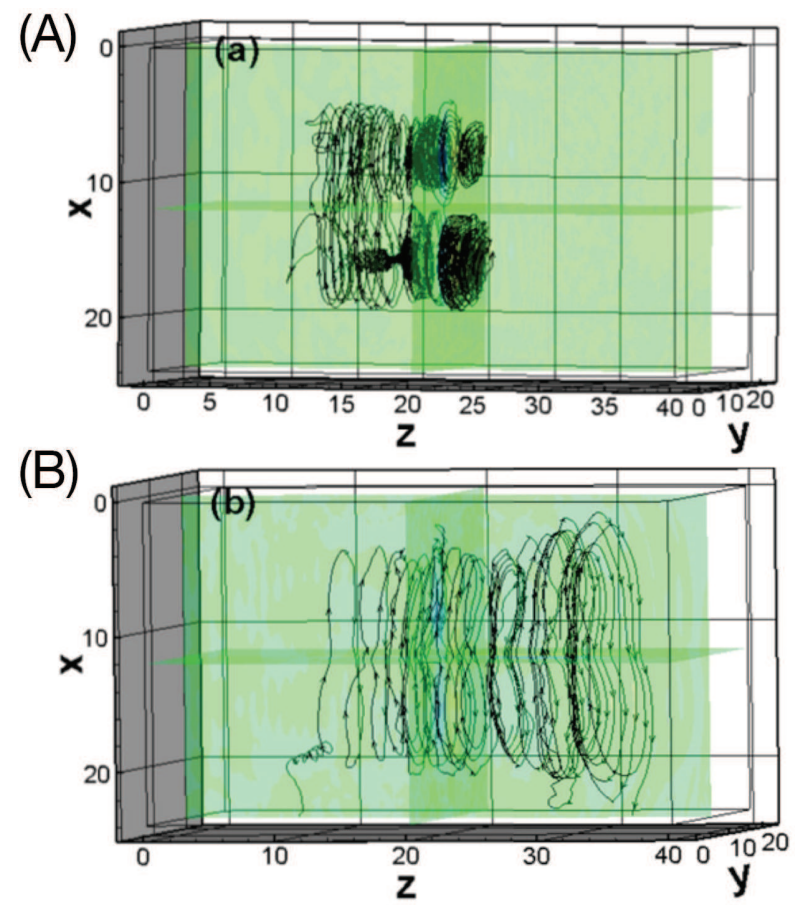

Fig. 5 Magnetic field lines in a near-critical density plasma (A) at $35 \mathrm{~T}_{0}$ and (B) at $50 \mathrm{~T}_{0}$, where $\mathrm{T}_{0}$ denotes laser period. Lasers propagate in the z-direction. ${ }^{26)}$
4. まとめ

本稿では、レーザーを用いた磁気リコネクション実験 について紹介した。磁気リコネクション現象では磁化プ ラズマの全体構造と局所的な拡散過程が結びついている ため，磁場全体を制御したうえで様々な計測手法を導入 できる室内実験は重要な役割を担っている。レーザーで 生成する高エネルギー密度プラズマで磁気リコネクショ ンを起こすためには10-100 T程度以上の非常に強い磁場 が必要となる。強磁場の生成方法で分類しながら，これ までに実施・提案されている代表的な実験例を示した。

レーザーによる磁気リコネクション実験は新しい研究 分野で，様々な強い反転磁場の生成/制御手法が提案さ れている段階にある。計測では光学測定によるプラズマ 全体の撮像が主で，リコネクション領域の定量的な状態 や磁力線のダイナミクスは, 実験からはあまり分かって いない。それぞれの磁場生成手法の特性に基づいた，リ コネクション研究としての問題設定や最適な計測手段の 整理が今後進んでいくものと思われる，一方，様々な構 造を持つ幅広い強度の磁場を扱えるため, これまでにな いリコネクション実験，特に天体観測の進展により重要 性が増している相対論/輻射プラズマ中の磁気リコネク ションに対する実験手段となることも期待される。

\section{参考文献}

1) D. Biskamp: Magnetic Reconnection in Plasmas (Cambridge University Press, 2000).

2) A. Lui: IEEE trans. Plasma Sci. 28 (2000) 1854.

3) E. Priest and T. Forbes: Astron. and Astrophys. Rev. 10 (2002) 313.

4) IT. Chapman: Plasma Phys. Contl. Fusion 53 (2011) 013001.

5) A. Vaivads, Y. Khotyaintsev, M. André, A. Retinò, S. C. Buchert, B. N. Rogers, P. Décréau, G. Paschmann, and T. D. Phan: Phys. Rev. Lett. 93 (2004) 105001.

6) W. Daughton, V. Roytershteyn, H. Karimabadi, L. Yin, B. J. Albright, B. Bergen, and K. J. Bowers: Nature Phys. 7 (2011) 539.

7) Y. Ono, H. Tanabe, Y. Hayashi, T. Ii, Y. Narushima, T. Yamada, M. Inomoto, and C. Z. Cheng: Phys. Rev. Lett. 107 (2011) 185001.

8) H. Ji, S. Terry, M. Yamada, R. Kulsrud, A. Kuritsyn, and Y. Ren: Phys. Rev. Lett. 92 (2004) 115001.

9) E. G. Zweibel and M. Yamada: Annu. Rev. Astron. Astrophys. 47 (2009) 291

10) M. Yamada, R. Kulsrud, and H. Ji: Rev. Mod. Phys. 82 (2010) 603.

11) P. Sweet: IAU Symp. 6 (1958) 123.

12) E. Parker: J. Geophys. Res. 62 (1957) 509.

13) J. Drake, M. Shay, and M. Swisdak: Phys. Plasmas 15 (2008) 042306.

14) M. Yamada, Y. Ren, H. Ji, J. Breslau, S. Gerhardt, R. Kulsrud, and A. Kuritsyn: Phys. Plasmas 13 (2006) 52119.

15) F. S. Mozer, S. D. Bale, and T. D. Phan: Phys. Rev. Lett. 89 (2002) 015002.

16) T. Moritaka and R. Horiuchi: Phys. Plasmas 15 (2008) 092114.

17) A. Ishizawa, R. Horiuchi, and H. Ohtani, Phys. Plasmas 11 (2004) 3579

18) H. Ji and W. Daughton: Phys. Plasmas 18 (2011) 111207.

19) G. Fiksel, W. Fox, A. Bhattacharjee, D. H. Barnak, P.-Y. Chang, K. Germaschewski, S. X. Hu, and P. M. Nilson: Phys. Rev. Lett. 113 (2014) 105003.

20) A. Schluter and L. Biermann: Zeit Nature Teil A5 (1950) 237.

21) J. Zhong, Y. Li, X. Wang, J. Wang, Q. Dong, C. Xiao, S. Wang, X. Liu, L. Zhang, L. An, et al.: Nature Phys. 6 (2010) 984.

22) M. Rosenberg, C. Li, W. Fox, I. Igumenshchev, F. Séguin, R. 
Town, J. Frenje, C. Stoeckl, V. Glebov, and R. Petrasso: Nature Comm. 6 (2015) 6190.

23) W. Fox, A. Bhattacharjee, and K. Germaschewski: Phys. Rev. Lett. 106 (2011) 215003.

24) H. Daido, F. Miki, K. Mima, M. Fujita, K. Sawai, H. Fujita, Y. Kitagawa, S. Nakai, and C. Yamanaka: Phys. Rev. Lett. 56 (1986) 846.
25) X. X. Pei, J. Y. Zhong, Y. Sakawa, Z. Zhang, K. Zhang, H. G. Wei, Y. T. Li, Y. F. Li, B. J. Zhu, T. Sano, et al. : Phys. Plasmas 23 (2016) 032125.

26) Y. L. Ping, J. Y. Zhong, Z. M. Sheng, X. G. Wang, B. Liu, Y. T. Li, X. Q. Yan, X. T. He, J. Zhang, and G. Zhao: Phys. Rev. E 89 (2014) 031101.

\section{レーザーワード}

アルベン波 (Alfvén wave)

巨視的な磁化プラズマ現象を記述する電磁流体 (MHD) 方程式には，2種類の磁気音波に加えてAlfvén波 と呼ばれる線形解が存在する。Alfvén波は音波のような 粗密波ではなく, Alfvén速度 $V_{\mathrm{A}}=B /(4 \pi \rho)^{1 / 2}$ で磁力線方向 に伝播する横波である $(B$ と $\rho$ は磁場強度とプラズマ質量 密度). その分散関係 $\omega=V_{\mathrm{A}} k$ は, 張力 $B^{2} / 4 \pi(=$ 磁気張 力), 密度 $\rho$ の弾性系を伝播する波として解釈すること ができる ( $\omega$ とkは周波数と波数). 磁気リコネクション
のMHDモデルでは，つなぎ変わった磁力線の張力に よってリコネクション領域からプラズマが排出されるた め，アウトフロー速度がAlfvén速度で与えられる。

Alfvén速度の定義で $\rho$ を電子質量密度に置き換えたもの は電子Alfvén速度と呼ばれ，電子にのみ凍結条件が成り 立つ, イオン慣性長やLarmor半径程度のスケールの微視 的現象で重要となる。

(森高 外征雄) 